\title{
Erratum to: Clinical and pathological outcomes of renal cell carcinoma (RCC) in native kidneys of patients with end-stage renal disease: a long-term comparative retrospective study with RCC diagnosed in the general population
}

\author{
Alberto Breda • Giuseppe Lucarelli • Oscar Rodriguez-Faba • Luis Guirado • \\ Carmen Facundo • Carlo Bettocchi • Loreto Gesualdo • Giuseppe Castellano • Giuseppe Grandaliano • \\ Michele Battaglia $\cdot$ Juan Palou $\cdot$ Pasquale Ditonno $\cdot$ Humberto Villavicencio
}

Published online: 28 February 2014

(C) Springer-Verlag Berlin Heidelberg 2014

Erratum to: World J Urol

DOI 10.1007/s00345-014-1248-y

One of the co-author's family name has been published incorrectly in the online publication. The correct family name should be Lucarelli (Giuseppe Lucarelli).

The online version of the original article can be found under doi:10.1007/s00345-014-1248-y.

A. Breda $(\bowtie) \cdot$ G. Lucarelli $(\bowtie) \cdot$ O. Rodriguez-Faba · J. Palou •

H. Villavicencio

Department of Urology, Fundació Puigvert, Universitat

Autonòma de Barcelona, c/Cartagena 340-350,

08025 Barcelona, Spain

e-mail: albbred@hotmail.com

G. Lucarelli

e-mail: giuseppe.lucarelli@inwind.it

G. Lucarelli $\cdot$ C. Bettocchi $\cdot$ M. Battaglia $\cdot$ P. Ditonno Urology, Andrology and Kidney Transplantation Unit, Department of Emergency and Organ Transplantation,

University of Bari, Piazza G. Cesare 11, 70124 Bari, Italy

L. Guirado $\cdot$ C. Facundo

Department of Nephrology, Fundació Puigvert, Universitat

Autonòma de Barcelona, Barcelona, Spain

L. Gesualdo · G. Castellano · G. Grandaliano

Dialysis and Transplantation Unit, Department of Emergency and Organ Transplantation, Nephrology, University of Bari,

Bari, Italy 